\title{
Male incubation feeding in songbirds responds differently to nest predation risk across hemispheres
}

\author{
Beata Matysiokováa ${ }^{\mathrm{a}, *}$, Andrew Cockburn ${ }^{\mathrm{b}, 1}$, Vladimír Remeš ${ }^{\mathrm{a}}$ \\ a Laboratory of Ornithology, Palacký University \\ ${ }^{\mathrm{b}}$ Division of Evolution, Ecology and Genetics, Australian National University
}

\section{A R T I C L E I N F O}

\section{Article history:}

Received 10 May 2011

Initial acceptance 1 July 2011

Final acceptance 7 September 2011

Available online 19 October 2011

MS. number: 11-00386

\section{Keywords:}

comparative analysis

incubation feeding

life history

nest predation

parental care

songbird
Evolution of parental care behaviour has been of considerable interest to behavioural ecologists for a long time. Incubation feeding, where an individual incubating eggs is provisioned by another individual, is an important component of avian parental care. It may be critical for breeding success by allowing the incubating bird to spend more time on the eggs. However, very little is known about environmental factors shaping incubation feeding, and incubation behaviour in general, of tropical and southern hemisphere birds, and how this differs compared to northern hemisphere species. We collated available data on the rate of incubation feeding in Australian, New Zealand and North American songbirds (78 species from 25 families). There was a strong positive relationship between female incubation attentiveness and incubation feeding by males; however, female attentiveness was higher in North America than in Australia and New Zealand for the same intensity of male incubation feeding. Incubation feeding was not related to species body mass, social organization, geographical latitude or ambient temperature. It differed significantly between families, but overall was not different between regions. Incubation feeding rate was related to nest predation rate, but differently in the two regions. It increased with nest predation rate in Australia and New Zealand, but decreased with nest predation rate in North America. We suggest that this may be caused by different predator-prey interactions in North America versus Australia and New Zealand, which could have shaped the evolution of incubation feeding differently.

(C) 2011 The Association for the Study of Animal Behaviour. Published by Elsevier Ltd. All rights reserved.
Understanding why species differ in patterns and intensity of parental care is a major focus of evolutionary behavioural studies (Clutton-Brock 1991). One of the key components of parental care in egg-laying organisms is caring for eggs (Deeming 2002). In birds, incubation of eggs is energetically demanding (Williams 1996; Thomson et al. 1998) and thus it can negatively influence condition and/or survival of the incubating individual (de Heij et al. 2006). In bird species with uniparental incubation, the female is usually responsible for incubating the eggs (Deeming 2002). Hence, she faces a trade-off between time- and energy-consuming incubation behaviour and foraging for self-maintenance (Drent 1975; Mertens 1977).

Males may feed the female during incubation (incubation feeding; Cottam 1941; Matysioková 2010), and this behaviour may

\footnotetext{
* Correspondence: B. Matysioková, Laboratory of Ornithology, Department of Zoology, Palacký University, Tř. Svobody 26, 77146 Olomouc, Czech Republic.

E-mail address: betynec@centrum.cz (B. Matysioková).

1 A. Cockburn is at the Division of Evolution, Ecology and Genetics, Research School of Biology, Australian National University, Canberra, ACT 0200, Australia.
}

be critical for maintaining female condition and incubation effort (von Haartman 1958; Røskaft 1983; Lyon \& Montgomerie 1985). Incubation feeding is widespread in birds (Kendeigh 1952), but species differ in the intensity of this behaviour (Martin \& Ghalambor 1999). This interspecific variability could be related to various environmental selective forces. For example, latitude is a strong predictor of life history characteristics, including clutch size and adult survival (Ghalambor \& Martin 2001). Thus, given that life history theory predicts a positive correlation between parental effort and adult mortality (Roff 1992), we might expect higher incubation feeding rates in areas with low adult survival. Species breeding in thermally extreme environments must protect their progeny from the negative effects of extreme temperatures. This effect could be even stronger during incubation, because the developing embryo is sensitive to both very low (below $26^{\circ} \mathrm{C}$ ) and very high (above $40.5^{\circ} \mathrm{C}$ ) temperatures (Webb 1987; Conway \& Martin 2000a). Thus, we might expect higher incubation feeding rates in species experiencing extreme ambient temperatures. Species might differ in parental care on the basis of their social organization as well. Males in species with helpers could be able to provide incubating females with more food that those that breed in pairs. Alternatively, male breeders in social 
species might take advantage of helping and decrease their own rate of incubation feeding, so there is no overall difference between cooperative and pair-breeding species (Hatchwell 1999). Finally, the risk of nest depredation might select for low activity around the nest that could lure nest predators (Ghalambor \& Martin 2001). Thus, we may expect a negative correlation between nest predation rate and incubation feeding intensity (Martin \& Ghalambor 1999).

Understanding factors shaping the occurrence and intensity of incubation feeding across species has been hindered by the paucity of broadscale, interspecific studies focusing on potential environmental selective forces. Moreover, studies conducted so far have focused on North American songbirds (Martin \& Ghalambor 1999; Conway \& Martin 2000b; Fontaine et al. 2007), with the exception of Auer et al. (2007) who studied birds of subtropical Argentina. The only two studies dealing with quantitative estimates of actual rates of incubation feeding were field studies and hence included only a limited number of species ( $N=19$ species, Martin \& Ghalambor 1999; $N=13$ species, Fontaine et al. 2007). The remaining studies reported just presence or absence of incubation feeding (Auer et al. 2007), or categorized the relative frequency of incubation feeding according to qualitative descriptions gained from the literature (Conway \& Martin 2000b).

To advance our understanding of male parental effort during incubation in birds, we performed the first broadscale comparative study of incubation feeding; moreover, we included both northern hemisphere species and the generally less studied southern hemisphere species of songbirds. We used all published information to obtain the rate of incubation feeding in 78 species of Australian, New Zealand and North American songbirds. We investigated behavioural, life history and environmental correlates of incubation feeding across species using contemporary phylogenetic hypotheses and phylogenetically informed statistical approaches. We expected higher incubation feeding rates in species living in areas indicative of low adult survival (northern hemisphere and further from the equator) and in species experiencing low, or extremely high, ambient temperatures and low nest predation rates. We expected either higher incubation feeding rates in cooperatively breeding species (positive effect of group size) or no difference when compared to pair-breeding species (load-lightening for the primary male). We included a possible allometric effect of adult body mass. We also investigated the relationship between female incubation effort and male incubation feeding to confirm the expected positive correlation across species.

\section{METHODS}

\section{Data Collection}

We collected data for this study from the literature. For data concerning incubation behaviour in North American songbirds we started with The Birds of North America (BNA, Poole \& Gill 1992-2002). We used Web of Science (available since 1945) to find articles that were either published after BNA or were not included in BNA. We searched by the scientific name of every species of North American songbirds for all articles whose title or abstract included any of the following words: attentiveness, biology, breeding biology, incubation, nest, nesting, nest failure, nest predation, parental care or reproductive success. We discarded all articles that were done on birds breeding in captivity. We located additional sources from papers obtained in the abovementioned way and from BNA.
For data concerning incubation behaviour in Australia and New Zealand we started with the Handbook of Australian, New Zealand, and Antarctic Birds (HANZAB) volumes 5, 6 and 7 (Higgins et al. 2001, 2006; Higgins \& Peter 2002). We searched Web of Science in the same way we did for North American species. Because the sample size obtained in this way was much lower than that for North American passerines, we additionally examined all volumes of major local Australian and New Zealand zoological journals (Australian Bird Watcher, Australian Field Ornithology, Australian Journal of Zoology, Australian Zoologist, Canberra Bird Notes, Corella, Notornis, Pacific Conservation Biology, South Australian Ornithologist, Sunbird, VOGR Notes and Western Australian Naturalist published after 2000), many of which are not indexed in Web of Science.

Original studies often provided only qualitative, verbal descriptions of the intensity of incubation feeding, rather than precise figures. These qualitative data were regarded as subjective and not comparable across studies; thus we included only articles that reported quantitative information (i.e. the number of feeds per hour of observation). To ensure comparability, we included only species with female-only incubation. As most studies provided information on only the rate of incubation feeding of females sitting on the nest, we excluded all studies where we could not distinguish between on- and off-nest incubation feeding, or studies describing only off-nest incubation feeding. We also excluded those studies where we were not able to distinguish between the feeding having occurred before the incubation and that occurring during incubation, as the former could be associated with courtship. In order not to include species in which incubation feeding does not occur at all, we excluded studies reporting zero rate of incubation feeding.

We obtained data on nest attentiveness and nest losses caused by nest predators from a comprehensive literature search similar to that used for incubation feeding (B. Matysioková \& V. Remeš, unpublished data). Nest attentiveness was defined as the percentage of the daytime hours a female spent incubating the eggs. If there was no such information in the original article but the lengths of incubation (on) and foraging (off) bouts were provided, we used those numbers to calculate nest attentiveness as: $100 \times($ mean on-bout duration/(mean on-bout duration + mean off-bout duration)) (Skutch 1962). The correlation between nest attentiveness obtained from original articles and calculated in this way was very high $\left(r_{74}=0.96\right.$; B. Matysioková, unpublished data).

In the analysis of incubation feeding and nest attentiveness, a simple correlation between incubation feeding per hour of observation and nest attentiveness might not signal a functional relationship. Instead, one might argue that the more time the female is on the nest, the more opportunity the male has to visit her with food. Thus, some authors have also used incubation feeding per attentive hour (as if the female were sitting $100 \%$ of the time on the eggs) instead of per hour of observation (Brewer 1961; McLaren 1975; Ritchison 1981). We calculated incubation feeding per attentive hour as: incubation feeding per hour of observation/(\% nest attentiveness/100). We also used this incubation feeding per attentive hour in our analysis of nest attentiveness to test for this potential bias. However, the rates of incubation feeding per hour of observation and per attentive hour were so highly correlated $\left(r_{72}=0.99\right)$ that different results were not anticipated.

For studies of male incubation feeding, we extracted information about the location of study site and year(s) and months of the study. We located geographical latitude where the study was done using Google Earth. The year(s) and months of the study were used to extract ambient temperature during incubation 
feeding. Temperature information was extracted from the databases of the Australian Bureau of Meteorology for Australian study sites, the National Institute of Water and Atmospheric Research (NIWA) for New Zealand study sites and the National Oceanic and Atmospheric Administration (NOAA) for North American study sites. We obtained mean monthly minimum and maximum temperatures, which were available from the respective agencies. We then calculated mean monthly temperature by taking the average from mean monthly minimum and maximum temperatures. We did so, because mean monthly temperatures were directly available for New Zealand and North America, but were not available for Australia. Thus, for consistency, we calculated monthly means from monthly minima and maxima for all regions. However, the correlation between thus calculated monthly mean temperatures and monthly mean temperatures available directly from the NIWA and NOAA was very high $\left(r_{80}=0.99\right.$; B. Matysioková, unpublished data), fully justifying our approach. If the particular study covered a longer period of time than was spanned by the incubation phase, we used just the months when the birds incubated to obtain temperature during incubation. The lowest ambient temperature in our data set was $3.1^{\circ} \mathrm{C}$, whereas the highest temperature was $24.9^{\circ} \mathrm{C}$, not even approaching the upper lethal temperature of $40.5^{\circ} \mathrm{C}$ (Conway \& Martin 2000a). Thus, we expected only a (negative) linear relationship between incubation feeding rate and ambient temperature and did not fit nonlinear effects in our model (see below).

We transformed data on predator-caused nest losses to daily predation rates by the method of Ricklefs (1969). To validate the values thus obtained, we also calculated daily predation rates by two other approaches (Beintema 1996; V. Remeš, unpublished data), which were based on the nest survival model of Mayfield (1975). Estimates produced by all three methods were highly correlated $\left(r_{59}=0.93,0.94\right.$ and 1.00$)$ and we used only values obtained by the method of Ricklefs (1969) in all statistical analyses. For all these transformations, the duration of the nest cycle was calculated as the sum of clutch size, incubation period and nestling period for each species. None of these methods estimates true daily predation rates that can be obtained by applying the Mayfield method (Mayfield 1975) on original data sets; these are obviously not available when working with literature data. However, we included the best available estimates of daily predation rates in our analyses, because overall proportion of depredated nests is a product of daily predation rate and the length of exposure. Thus, excluding daily rates could lead to biased results (for details, see Remeš \& Martin 2002). For each species on our list, we obtained information on adult body mass (g; Higgins et al. 2001, 2006; Higgins \& Peter 2002; Poole \& Gill 1992-2002) and social organization (cooperative versus pair breeding, Cockburn 2006). Our data set is presented in Appendix Table A1.

Table 1

Multivariate analysis relating incubation feeding rate to environmental factors and covariates across species using phylogenetic generalized least squares

\begin{tabular}{lrrr}
\hline Factor & Estimate (SE) & \multicolumn{1}{c}{$F$} & \multicolumn{1}{c}{$P$} \\
\hline Intercept & $-0.291(0.821)$ & & \\
Body mass & $0.006(0.177)$ & $<0.01$ & 0.978 \\
Social organization (pair) & $-0.237(0.185)$ & 2.11 & 0.153 \\
Latitude & $0.025(0.013)$ & 0.04 & 0.841 \\
Temperature & $0.001(0.001)$ & 0.02 & 0.885 \\
Region (AU \& NZ) & $0.292(0.196)$ & 1.82 & 0.184 \\
Nest predation & $-7.633(1.957)$ & 5.71 & 0.021 \\
Nest predation*Region (AU \& NZ) & $15.360(4.077)$ & 14.19 & $<0.001$ \\
\hline
\end{tabular}

Reference levels of categorical variables are given in parentheses. Overall $R^{2}=0.32$, $N=60$.

\section{Data Analysis}

The primary aim of this study was to collate all available information on the rate of incubation feeding in Australian, New Zealand and North American songbirds and to perform comparative analyses to infer possible factors responsible for the variation in the intensity of incubation feeding among species. We included factors that had previously been shown to be important (e.g. Conway \& Martin 2000b) or could be reasonably expected to be important based on the current understanding of the incubation behaviour in birds (reviewed in Deeming 2002). The factors included in the analysis of incubation feeding are presented in Table 1.

We fitted a model with the mean incubation feeding rate weighted by sample size (in hours of observation) for individual species as a dependent variable. Sometimes we had information on the rate of incubation feeding from more than one population, but were not able to find out the sample size in one or more of these populations. We excluded such population(s) from the analyses. This enabled us to weight the species' mean calculated based on the remaining populations. In two species (Bombycilla cedrorum and Pyrocephalus rubinus), we were not able to find out the sample size in either of two populations so we left the means for these two species unweighted. We fitted linear effects but also allowed the relationships to differ between North America and Australia/New Zealand by fitting interactions with region. We retained all linear effects in the models, but excluded nonsignificant interactions. To investigate whether incubation feeding predicts female incubation effort across species we fitted a model with the average nest attentiveness weighted by sample size (in hours) for individual species as a dependent variable. In all the analyses body mass was log transformed, incubation feeding rate and daily predation rate were square-root transformed and temperature was raised to the power of two. These transformations were chosen because they best approximated normal distributions of the variables. However, to test the robustness of our results to the particular transformations, we also repeated analyses with alternative transformations (log instead of square root in the case of incubation feeding, no transformation instead of square root in the case of daily predation rate). Results remained unchanged. Latitude and nest attentiveness were always left untransformed. Predictors that remained in interactions were centered to allow the interpretation of both the interaction term and main effects (Engqvist 2005).

Phylogenetic relationships among species might cause statistical nonindependence of residuals, thus violating assumptions of standard statistical tests. Therefore we fitted our models by generalized least squares in the APE package for R (Paradis 2006). This is a flexible approach that allows for optimal adjustment of the phylogenetic autocorrelation of residuals (Pagel's $\lambda$ parameter) and fitting of both univariate and multivariate models (Revell 2010). For these phylogenetically corrected analyses, we assembled a working phylogeny based on the most recent molecular phylogenies (Barker et al. 2004; Miller \& Lambert 2006; Loynes et al. 2009; see Appendix Fig. A1). As this working phylogeny came from diverse sources, we arbitrarily set branch lengths to equal the number of species minus one (Grafen 1989). Results were identical when we used branch lengths equal to unity (B. Matysiokova \& V. Remes, unpublished data).

\section{RESULTS}

Altogether, we collected data on the rate of incubation feeding performed on the nest from 109 populations of 78 species of North American, Australian and New Zealand songbirds belonging to 25 


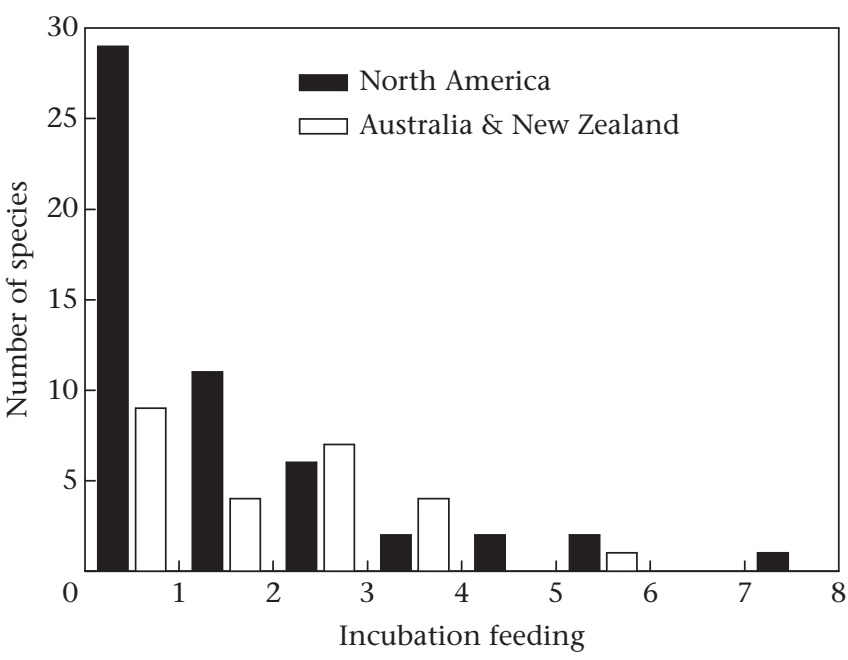

Figure 1. Distribution of incubation feeding (per hour of observation) for North America and Australia plus New Zealand. The lowest values are not zeros, but values of incubation feeding between zero and one (see Methods).

families. We were not able to find out the sample size in six of the populations so we excluded them from the analyses (see Methods). Of the remaining 103 populations, 75 (53 species, 14 families) were from North America and 28 ( 25 species, 12 families) from Australia and New Zealand. We found the geographical latitude in 102 and ambient temperature during incubation in 101 of these populations. Of all 78 species, 21 were cooperative breeders. We obtained data on nest predation rate for 61 species and data on nest attentiveness for 74 species.

Incubation feeding rate ranged from 0.02 to 7.41 feedings per hour of observation across species (mean $\pm \mathrm{SD}=1.57 \pm 1.53$,

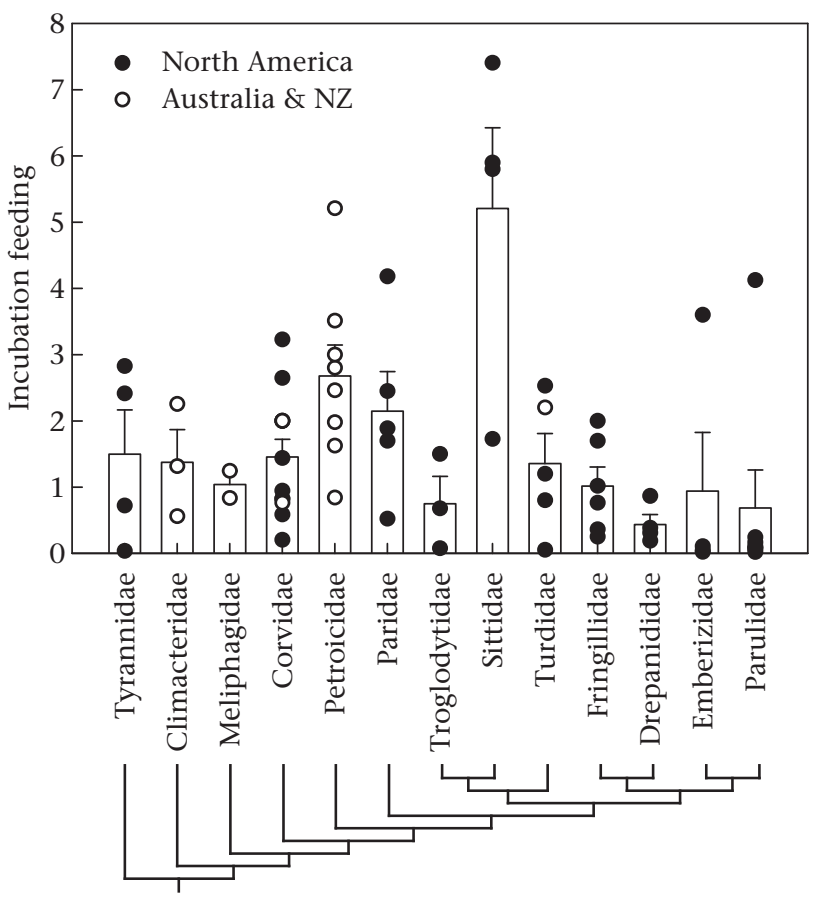

Figure 2. Incubation feeding (per hour of observation) for 13 taxonomic families with data on incubation feeding in two or more species. Bars are family means (1 SE); dots are values for individual species.

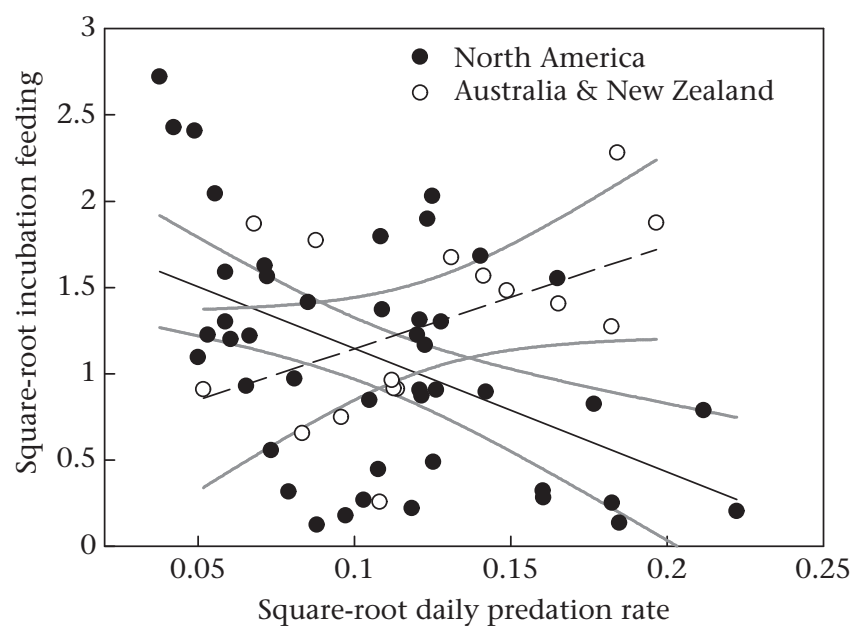

Figure 3. Relationship of the rate of incubation feeding (per hour of observation) to daily nest predation rate across species and regions $(N=60)$, with $95 \%$ confidence intervals around regression lines.

median $=1.11, N=78$ ), and did not differ significantly between North America and Australia/New Zealand $\left(F_{176}=0.37, P=0.544\right.$; Fig. 1). Families differed in the average species-specific incubation feeding rate $\left(\mathrm{F}_{23,54}=2.37, P=0.005, N=78\right.$; Fig. 2$)$. Nest attentiveness ranged from $52.0 \%$ to $98.2 \%$ (mean $\pm \mathrm{SD}=78.85 \pm 10.52$ median $=79.22, N=74$ ) and was significantly higher in North American species than in Australia and New Zealand $\left(F_{1,72}=8.33\right.$, $P=0.005)$.

Incubation feeding rate was related to nest predation rate, but differently in the two regions. It increased with nest predation rate in Australia and New Zealand but decreased with nest predation rate in North America (Table 1, Fig. 3). Incubation feeding rate did not differ significantly between cooperative and pair-breeding species and was not significantly related to adult body mass, geographical latitude or ambient temperature (Table 1 ). Our data confirmed that nest attentiveness increased with the rate of incubation feeding $\left(F_{1,69}=11.67\right.$, $P=0.001$ ). Nest attentiveness was also higher in North America than in Australia and New Zealand even after accounting for other variables $\left(F_{1,69}=9.09, P=0.004 ;\right.$ Fig. 4$)$. It was not significantly related to

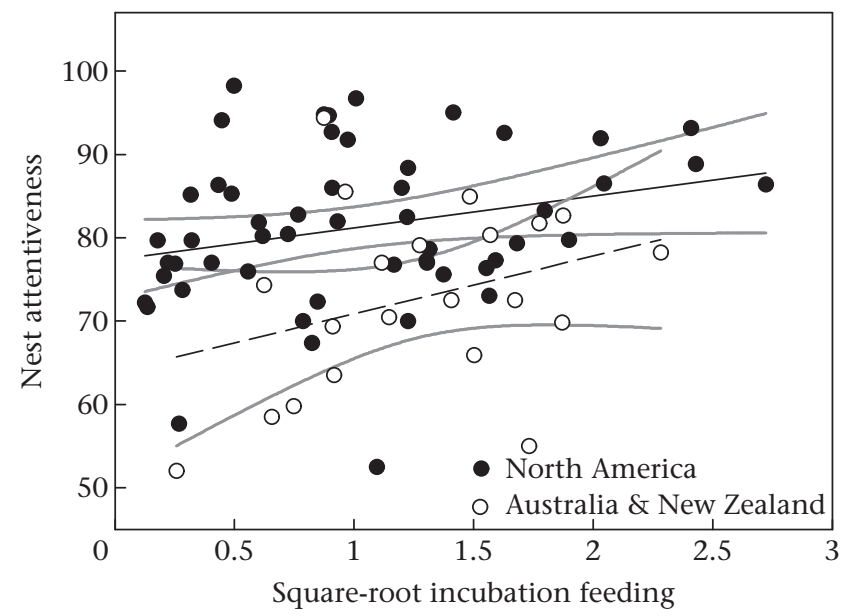

Figure 4. Relationship of nest attentiveness (in \%) to the rate of incubation feeding (per hour of observation) across species and regions $(N=74)$, with $95 \%$ confidence intervals around regression lines. 
adult body mass $\left(F_{1,69}=1.42, P=0.237\right)$ or social organization $\left(F_{1,69}=2.06, P=0.155\right.$; overall $\left.R^{2}=0.27\right)$. The results did not change when we used incubation feeding per attentive hour instead of simply incubation feeding per hour of observation. Nest attentiveness still increased significantly with the rate of incubation feeding per attentive hour $\left(F_{1,69}=5.89, P=0.018\right)$, even when adjusted for all other factors (overall $R^{2}=0.28$ ).

The degree of phylogenetic autocorrelation was low in both analyses. The estimate of Pagel's $\lambda$ was 0.01 for incubation feeding rate and 0.34 for nest attentiveness indicating that both these behaviours undergo rapid adaptive evolution.

\section{DISCUSSION}

On average, rates of male incubation feeding in North American songbirds were similar to the rates in Australian and New Zealand songbirds. However, the patterns in relation to nest predation rates differed strongly. In North American species male incubation feeding rates decreased with increasing nest predation rates, whereas in Australian and New Zealand species they increased. Higher incubation feeding rates lead to more activity in the vicinity of the nest, which may lure nest predators. We thus expected to find lower rates of incubation feeding in species suffering from higher risk of nest depredation. However, only North American species conformed to this expectation, whereas Australian and New Zealand species ran directly against it. How can we explain these surprising results?

Male incubation feeding has both benefits and costs. First, male incubation feeding rates were previously demonstrated to correlate positively with female nest attentiveness (Martin \& Ghalambor 1999; Tewksbury et al. 2002; Fontaine et al. 2007; Lloyd et al. 2009), and this pattern was confirmed by this study as well. In addition, an increase in nest attentiveness can contribute to shorter incubation periods (Haftorn 1983; Lyon \& Montgomerie 1985; Martin 2002; Martin et al. 2007). Decreases of this sort in the length of the development period in the nest, which is typically the period of high offspring mortality (Roff et al. 2005), are an effective way to increase fitness (Lack 1968; Remeš \& Martin 2002). Hence, selection could favour an increase in nest attentiveness and therefore in the rate of incubation feeding in species suffering from higher rates of nest depredation (Fontaine \& Martin 2006). By contrast, it has been assumed that high activity around the nest leads to high nest predation rate within species. The expression of this cost over evolutionary time is expected to translate into a negative relationship between nest predation risk (caused by e.g. high density of nest predators in the environment) and activity around the nest at the interspecific level (Martin et al. 2000). Hence, selection should favour a decrease in the rate of incubation feeding in species under high nest depredation risk (Martin \& Ghalambor 1999).

The relative importance of benefits and costs of male incubation feeding may depend on the nest-searching strategies of principal predators. If most nest predators locate nests by sight, it might be better to decrease the activity around the nest with increasing nest predation risk and thus avoid nest disclosure even at the cost of a longer incubation period. On the other hand, if nest predators locate nests at random, or based on other cues than parental activity, higher incubation feeding rate will not bear the cost of nest disclosure. Moreover, it might allow for higher nest attentiveness (this study) and a shorter incubation period (Lyon \& Montgomerie 1985; Nilsson \& Smith 1988) with the benefit of shortening the exposure of the nest to the risk of mortality. Thus, one explanation for our findings might be that predator-prey interactions differ between North America and Australia/New Zealand. In North America, benefits of avoiding nest disclosure might be more important, whereas in Australia and New Zealand, benefits of shortening the incubation period with increasing nest depredation risk might prevail. However, data on nest predator identity are still sparse (Thompson 2007; Weidinger 2008) and unfortunately do not allow for any quantitative inference. Our hypothesis thus remains to be evaluated in the future.

Annual reproductive effort typically declines with increasing adult survival rate (Roff 1992). This may be the cause of lower reproductive effort in the tropics and southern latitudes where adult survival rate is generally higher compared to northern latitudes (Rowley \& Russell 1991; Ghalambor \& Martin 2001). Hence, we predicted that the rate of incubation feeding (a component of reproductive effort) would be lower in Australia (where adult survival rates are typically high, Rowley \& Russell 1991; Yom-Tov et al. 1992) and would increase from the equator towards more temperate, either southern or northern latitudes. There was no such pattern in our data, which suggests that adult survival is probably not a driving force behind the evolution of male incubation feeding. On the contrary, we found higher female nest attentiveness for the same amount of male incubation feeding in North America than in Australia and New Zealand (Fig. 4). This suggests that male and female parental investment during incubation might be under the influence of different environmental factors. More detailed analyses of female incubation behaviour could reveal which factors might be responsible for the difference between regions we identified here.

Alternative hypotheses have been suggested for the relationship between incubation feeding, adult survival and pair bond duration. A male might invest heavily in feeding the incubating female as a way of ensuring that in case of nest failure she will start a new nest with him and will not search for a different mate (pair bond maintenance hypothesis; Lack 1940). Moreover, in species with high adult survival and long-term pair bonds, males might invest in incubating females so that females do not suffer so much from reproductive costs and are in better condition for future breeding attempts. We were not able to test the first hypothesis (pair bond maintenance) and our data were not consistent with the second hypothesis, because there was no relationship between latitude (indicative of adult survival) and incubation feeding frequency.

A negative correlation between incubation feeding rate and ambient temperature during incubation is typically found at the intraspecific level (Nilsson \& Smith 1988; Pearse et al. 2004; Matysioková \& Remeš 2010). This is usually explained by increasing energy expenditure of incubating females with declining temperature (Biebach 1981; Haftorn \& Reinertsen 1985; de Heij et al. 2008). Therefore, it is surprising that we did not find a similar relationship at the interspecific level. One possible explanation for the absence of geographical and temperature effects on incubation feeding could be that they are important for the evolution of off-nest incubation feeding, whereas the evolution of on-nest incubation feeding might be under the influence of nest predation risk (see above). Indeed, onand off-nest incubation feeding rates correlated weakly across species $\left(r_{10}=0.34, P=0.28\right)$ suggesting that their independent evolution is at least possible.

Social and sexual relationships might also affect parental care strategies. For example, males that are less sure about their paternity might invest less in the current brood (Sheldon 2002), which might even have led to a negative covariation between extrapair paternity rate and male paternal contribution across species (Møller \& Birkhead 1993). Here we did not study effects of paternity but focused on social organization. However, we did not find a significant difference between cooperatively and pair-breeding species in the rate of incubation feeding by male(s). In some species, incubation feeding rate was higher in groups than in solitarily breeding pairs (Lloyd et al. 2009) or it correlated positively 
with the number of helpers in the group (Doerr \& Doerr 2007); however, this was not true in other species (Radford 2002, 2004). Moreover, in one study incubation feeding rate by the male breeder correlated negatively with group size (Ligon \& Ligon 1978). These findings suggest that male breeders often use the load-lightening strategy whereby they reduce their parental investment at the cost of helpers, which has been demonstrated across species for other components of parental care (Hatchwell 1999). This explanation is also in line with our own results obtained for incubation feeding by male(s).

\section{Acknowledgments}

We are grateful to Miloš Krist and three anonymous referees for helpful comments on the manuscript. This work was supported by an Endeavour Research Fellowship to V.R. (661/2008), a mobility grant from Palacký University to B.M., and the Czech Ministry of Education (MSM6198959212).

\section{References}

Amadon, D. 1944. Results of the Archbold expeditions. No. 50. A preliminary life history study of the Florida jay Cyanocitta c. coerulescens. American Museum Novitates, 1252, 1-22.

Auer, S. K., Bassar, R. D., Fontaine, J. J. \& Martin, T. E. 2007. Breeding biology of passerines in a subtropical montane forest in northwestern Argentina. Condor, 109, 321-333.

Barker, F. K., Cibois, A., Schikler, P., Feinstein, J. \& Cracraft, J. 2004. Phylogeny and diversification of the largest avian radiation. Proceedings of the National Academy of Sciences, U.S.A., 101, 11040-11045.

Beintema, A. J. 1996. Inferring nest success from old records. Ibis, 138, 568-570.

Bent, A. C. 1968. Life histories of North American cardinals, grosbeaks, buntings, towhees, finches, sparrows, and allies. Order Passeriformes: Family Fringillidae. Genera Richmondena through Pipilo (part). U.S. National Museum Bulletin, 237, 453-456.

Biebach, H. 1981. Energetic costs of incubation on different clutch sizes in starlings (Sturnus vulgaris). Ardea, 69, 141-142.

Boulton, R., Richard, Y. \& Armstrong, D. P. 2010. The effect of male incubation feeding, food and temperature on the incubation behaviour of New Zealand robins. Ethology, 115, 1-8.

Brewer, R. 1961. Comparative notes on the life history of the Carolina chickadee. Wilson Bulletin, 73, 348-373.

Buitron, D. 1988. Female and male specialization in parental care and its consequences in black-billed magpies. Condor, 90, 29-39.

Butler, R. W., Verbeek, N. A. M. \& Richardson, H. 1994. The breeding biology of the northwestern crow. Wilson Bulletin, 96, 408-418.

Clutton-Brock, T. H. 1991. The Evolution of Parental Care. Princeton, New Jersey: Princeton University Press.

Cockburn, A. 2006. Prevalence of different modes of parental care in birds. Proceedings of the Royal Society B, 273, 1375-1383.

Conway, C. J. \& Martin, T. E. 2000a. Effects of ambient temperature on avian incubation strategies: a model and test. Behavioral Ecology, 11, 178-188.

Conway, C. J. \& Martin, T. E. 2000b. Evolution of passerine incubation behavior: influence of food, temperature, and nest predation. Evolution, 54, $670-685$.

Cottam, C. 1941. Incubation feeding of Calliope hummingbird. Auk, 58, 59-60.

Coventry, P. 1988. Notes on the breeding behaviour of the red-capped robin. Australian Bird Watcher, 12, 209-216.

Coventry, P. 1989. Notes on the scarlet robin. Australian Bird Watcher, 13, 68-69.

Davis, D. E. 1959. Observations on territorial behavior of least flycatchers. Wilson Bulletin, 71, 73-85.

Davis, J. 1960. Nesting behavior of the rufous-sided towhee in coastal California Condor, 62, 434-456.

Davis, J., Fisler, G. F. \& Davis, B. S. 1963. The breeding biology of the western flycatcher. Condor, 65, 337-382.

Debus, S., Boland, B. \& Koboroff, A. 2004. Breeding of the eastern yellow robin in an exotic pine plantation at Armidale, New South Wales. Australian Field Ornithology, 21, 166-169.

Deeming, D. C. 2002. Behaviour patterns during incubation. In: Avian Incubation. Behaviour, Environment, and Evolution (Ed. by D. C. Deeming), pp. 63-87. New York: Oxford University Press.

Dickinson, J. L. \& Leonard, M. L. 1995. Mate attendance and copulatory behaviour in western bluebirds: evidence of mate guarding. Animal Behaviour, 52, 981-992.

Dobbs, R. C. 2005. Breeding biology of dusky flycatchers in a southern Utah mixed conifer-aspen woodland. Journal of Field Ornithology, 76, 183-192.
Doerr, E. D. \& Doerr, V. A. J. 2007. Positive effects of helpers on reproductive success in the brown treecreeper and the general importance of future benefits. Journal of Animal Ecology, 76, 966-976.

Doerr, V. A. J. 2004. A comparative approach to cooperative breeding: demography, helping behavior, and population genetics of Australasian treecreepers. Ph.D. thesis, University of Nevada.

Drent, R. 1975. Incubation. In: Avian Biology. Vol. 5 (Ed. by D. S. Farner, J. R. King \& K. C. Parkes), pp. 333-420. New York: Academic Press.

Eikenaar, C., Berg, L. \& Komdeur, J. 2003. Experimental evidence for the influence of food availability on incubation attendance and hatching asynchrony in the Australian reed warbler Acrocephalus australis. Journal of Avian Biology, 34 419-427.

Engqvist, L. 2005. The mistreatment of covariate interaction terms in linear mode analyses of behavioural and evolutionary ecology studies. Animal Behaviour, 70, 967-971.

Erpino, M. J. 1968. Nest-related activities of black-billed magpies. Condor, 70 154-165.

Fontaine, J. J. \& Martin, T. E. 2006. Parent birds assess nest predation risk and adjust their reproductive strategies. Ecology Letters, 9, 428-434.

Fontaine, J. J., Martel, M., Markland, H. M., Niklison, A. M., Decker, K. L. \& Martin, T. E. 2007. Testing ecological and behavioral correlates of nest predation. Oikos, 116, 1887-1894.

Frith, D. W. \& Frith, C. B. 2000. The nesting biology of the grey-headed robin Heteromyias albispecularis (Petroicidae) in Australian upland tropical rainforest. Еmu, 100, 81-94.

Ghalambor, C. K. \& Martin, T. E. 2001. Fecundity-survival trade-offs and parental risk-taking in birds. Science, 292, 494-497.

Ghalambor, C. K. \& Martin, T. E. 2002. Comparative manipulation of predation risk in incubating birds reveals variability in the plasticity of responses. Behavioral Ecology, 13, 101-108.

Gill, B. J. 1993. Notes on the nesting and longevity of whiteheads. Notornis, 40 $141-143$.

Grafen, A. 1989. The phylogenetic regression. Philosophical Transactions of the Royal Society $B$, 326, 119-157.

von Haartman, L. 1958. The incubation rhythm of the female pied flycatcher (Ficedula hypoleuca) in the presence and absence of the male. Ornis Fennica, 35 71-76.

Haftorn, S. 1983. Egg temperature during incubation in the great tit Parus major, in relation to ambient temperature, time of day, and other factors. Fauna Norvegica, 6, 22-38.

Haftorn, S. \& Reinertsen, R. E. 1985. The effect of temperature and clutch size on the energetic cost of incubation in free-living blue tit (Parus caeruleus). Auk, 102 $470-478$.

Hardy, J. W. 1961. Studies in behavior and phylogeny of certain New World jays (Garrulinae). University of Kansas Science Bulletin, 42, 13-149.

Hatchwell, B. J. 1999. Investment strategies of breeders in avian cooperative breeding systems. American Naturalist, 154, 205-219.

de Heij, M. E., van den Hout, P. J. \& Tinbergen, J. M. 2006. Fitness cost of incubation in great tits (Parus major) is related to clutch size. Proceedings of the Royal Society B, 273, 2353-2361.

de Heij, M. E., Ubels, R., Visser, G. H. \& Tinbergen, J. M. 2008. Female great tits Parus major do not increase their daily energy expenditure when incubating enlarged clutches. Journal of Avian Biology, 39, 121-126.

Higgins, P. J. \& Peter, J. M. 2002. Handbook of Australian, New Zealand and Antarctic Birds. Vol. 6: Pardalotes to Shrike-thrushes. Melbourne: Oxford University Press.

Higgins, P. J., Peter, J. M. \& Steele, W. K. 2001. Handbook of Australian, New Zealand and Antarctic Birds. Vol. 5: Tyrant-flycatchers to Chats. Melbourne: Oxford University Press.

Higgins, P. J., Peter, J. M. \& Cowling, S. J. 2006. Handbook of Australian, New Zealand and Antarctic Birds. Vol. 7: Boatbill to Starlings. Melbourne: Oxford University

Innes, J. \& Hay, R. 1995. The nesting of the North Island kokako (Callaeas cinerea wilsoni): review of accounts from 1880 to 1989. Notornis, 42, 79-93.

Jawor, J. M. \& Breitwisch, R. 2006. Is mate provisioning predicted by ornamentation? A test with northern cardinals (Cardinalis cardinalis). Ethology, 112, $888-895$

Johnson, L. S. \& Kermott, L. H. 1992. Why do male house wrens feed their incubating mates so rarely? American Midland Naturalist, 127, 200-203.

Kearton, P. M. 1979. The breeding biology and behaviour of the yellow-breasted tit (Petroica macrocephala macrocephala). M.Sc. thesis, University of Canterbury.

Kendeigh, S. C. 1952. Parental care and its evolution in birds. Illinois Biological Monographs, 22, 1-356.

Kepler, C. B., Pratt, T. K., Ecton, A. E., Jr. \& Flutsch, K. M. 1996. Nesting behavior of the poo-uli. Wilson Bulletin, 108, 620-638.

Kilham, L. 1989. The American Crow and the Common Raven. College Station: Texas A\&M University Press.

King, B. R. 1980. Social organization and behaviour of the grey-crowned babbler Pomatostomus temporalis. Emu, 80, 59-76.

Klatt, P. H., Stutchbury, B. J. M. \& Evans, M. L. 2008. Incubation feeding by male scarlet tanagers: a mate removal experiment. Journal of Field Ornithology, 79, $1-10$

Lack, D. 1940. Courtship feeding in birds. Auk, 57, 169-178.

Lack, D. 1968. Ecological Adaptations for Breeding in Birds. London: Chapman \& Hall. 
Lawrence, L. de K 1949. The red crossbill at Pimisi bay, Ontario. Canadian FieldNaturalist, 63, 147-160.

Lawrence, L. de K 1953. Notes on the nesting behavior of the blackburnian warbler. Wilson Bulletin, 65, 135-144

Ligon, J. D. \& Ligon, S. H. 1978. The communal social system of the green woodhoopoe in Kenya. Living Bird, 17, 1663-1669.

Linsdale, J. M. 1957. Goldfinches on the hastings natural history reservation. American Midland Naturalist, 57, 1-119.

Lloyd, P., Taylor, W. A., du Plessis, M. A. \& Martin, T. E. 2009. Females increase reproductive investment in response to helper-mediated improvements in allofeeding, nest survival, nestling provisioning and post-fledging survival in the Karoo scrub-robin Cercotrichas coryphaeus. Journal of Avian Biology, 40, 400-411.

Loynes, K., Joseph, L. \& Keogh, J. S. 2009. Multi-locus phylogeny clarifies the systematics of the Australo-Papuan robins (Family Petroicidae, Passeriformes). Molecular Phylogenetics and Evolution, 53, 212-219.

Lyon, B. E. \& Montgomerie, R. D. 1985. Incubation feeding in snow buntings: female manipulation or indirect male parental care? Behavioral Ecology and Sociobiology, 17, 279-284.

Lyon, B. E. \& Montgomerie, R. D. 1987. Ecological correlates of incubation feeding: a comparative study of high arctic finches. Ecology, 68, 713-722.

McLaren, M. A. 1975. Breeding biology of the boreal chickadee. Wilson Bulletin, 87, 344-354.

McNair, D. B. 1984. Breeding biology of the fish crow. Oriole, 49, 21-32.

Maguire, G. S. \& Mulder, R. A. 2004. Breeding biology and demography of the southern emu-wren (Stipiturus malachurus). Australian Journal of Zoology, 52, 583-604.

Marchant, S. 1984. Notes on the breeding of varied sittellas. Corella, 8, 11-15.

Marchant, S. 1986. Nesting notes on the white-naped honeyeater. Australian Birds 20, 52-54

Martin, T. E. 2002. A new view of avian life-history evolution tested on an incubation paradox. Proceedings of the Royal Society B, 269, 309-316.

Martin, T. E. \& Ghalambor, C. K. 1999. Males feeding females during incubation. Required by microclimate or constrained by nest predation? American Naturalist, 153, 131-139.

Martin, T. E., Scott, M. \& Menge, C. 2000. Nest predation increases with parental activity: separating nest site and parental activity effects. Proceedings of the Royal Society B, 267, 2287-2293.

Martin, T. E., Auer, S. K., Bassar, R. D., Niklison, A. M. \& Lloyd, P. 2007. Geographic variation in avian incubation periods and parental influences on embryonic temperature. Evolution, 61, 2558-2569.

Marzluff, J. M. \& Balda, R. P. 1992. Pinyon jays: making the best of a bad situation by helping. In: Cooperative Breeding in Birds (Ed. by P. B. Stacey \& W. D. Koenig), pp. 197-238. Cambridge: Cambridge University Press.

Matysioková, B. 2010. Incubation feeding in birds. Sylvia, 46, 3-21.

Matysioková, B. \& Remeš, V. 2010. Incubation feeding and nest attentiveness in a socially monogamous songbird: role of feather colouration, territory quality, and ambient environment. Ethology, 116, 596-607.

Mayfield, H. F. 1975. Suggestions for calculating nest success. Wilson Bulletin, 87, 456-466.

Mertens, J. A. L. 1977. The energy requirements for incubation in great tits, Parus major L. Ardea, 65, 184-196.

Miller, H. C. \& Lambert, D. M. 2006. A molecular phylogeny of New Zealand's Petroica (Aves: Petroicidae) species based on mitochondrial DNA sequences. Molecular Phylogenetics and Evolution, 40, 844-855.

Møller, A. P. \& Birkhead, T. R. 1993. Certainty of paternity covaries with paterna care in birds. Behavioral Ecology and Sociobiology, 33, 261-268.

Nice, M. N. \& Thomas, R. H. 1948. Nesting of the Carolina wren. Wilson Bulletin, 60, $139-158$

Nilsson, J.-A. \& Smith, H. K. 1988. Incubation feeding as a male tactic for early hatching. Animal Behaviour, 36, 641-647.

Nolan, P. M., Stoehr, A. M., Hill, G. F. \& McGraw, K. J. 2001. The number of provisioning visits by house finches predicts the mass of food delivered. Condor 103, 851-855.

Nolan, V., Jr. 1958. Anticipatory food-bringing in the prairie warbler. Auk, $\mathbf{7 5}$ $263-278$.

Nolan, V., Jr. 1978. The ecology and behavior of the prairie warbler Dendroica discolor. Ornithological Monographs, 26, 1-593.

Norris, R. A. 1958. Comparative biosystematics and life history of the nuthatches Sitta pygmaea and Sitta pusilla. University of California Publications in Zoology, $\mathbf{5 6}$ 119-300.

Noske, R. A. 1991. A demographic comparison of cooperatively breeding and noncooperative treecreepers (Climacteridae). Emu, 91, 73-86.

Odum, E. P. 1942. Annual cycle of the black-capped chickadee: 2. Auk, 58 518-535.

Offutt, G. C. 1965. Behavior of the tufted titmouse before and during the nesting season. Wilson Bulletin, 77, 382-387.

Oliarnyk, C. J. \& Robertson, R. J. 1996. Breeding behavior and reproductive success of cerulean warblers in southeastern Ontario. Wilson Bulletin, 108, 673-684.

Otter, K., Ramsay, S. M. \& Ratcliffe, L. 1999. Enhanced reproductive success of female black-capped chickadees mated to high-ranking males. Auk, 116, 345-354.

Paradis, E. 2006. Analysis of Phylogenetics and Evolution with R. New York: Springer.
Pearse, A. T., Cavitt, J. F. \& Cully, J. F., Jr. 2004. Effects of food supplementation on female nest attentiveness and incubation mate feeding in two sympatric wren species. Wilson Bulletin, 116, 23-30.

Perry, A. E. 1965. The nesting of the pine siskin in Nebraska. Wilson Bulletin, 77, 243-250.

Poiani, A. 1992. Feeding of the female breeder by male helpers in the bell miner Manorina melanophrys. Emu, 92, 233-237.

Poole, A. \& Gill, F. 1992-2002. The Birds of North America. Philadelphia: The Birds of North America.

Powlesland, R. G. 1983. Breeding and mortality of the South Island robin in Kowhai Bush, Kaikoura. Notornis, 3, 265-282.

Putnam, L. S. 1949. The life history of the cedar waxwing. Wilson Bulletin, 61, 141-182.

Radford, A. N. 2004. Incubation feeding by helper influences female nest attendance in the green woodhoopoe, Phoeniculus purpureus. Behavioral Ecology and Sociobiology, 55, 583-588.

Radford, J. 2002. Conservation ecology and breeding biology of the white-browed treecreeper Climacteris affinis. Ph.D. thesis, Deakin University.

Remeš, V. \& Martin, T. E. 2002. Environmental influences on the evolution of growth and developmental rates in passerines. Evolution, 56 2505-2518.

Revell, L. J. 2010. Phylogenetic signal and linear regression on species data. Methods in Ecology and Evolution, 1, 319-329.

Ricklefs, R. E. 1969. An analysis of nesting mortality in birds. Smithsonian Contributions to Zoology, 9, 1-48.

Ritchison, G. 1981. Breeding biology of the white-breasted nuthatch. Loon, 53, 184-187.

Roff, D. A. 1992. The Evolution of Life Histories: Theory and Analysis. New York: Chapman \& Hall.

Roff, D. A., Remeš, V. \& Martin, T. E. 2005. The evolution of fledging age in songbirds. Journal of Evolutionary Biology, 18, 1425-1433.

Røskaft, E. 1983. Sex-role partitioning and parental care by the rook Corvus frugilegus. Ornis Scandinavica, 14, 180-187.

Rowley, I. \& Russell, E. 1991. Demography of Passerines in the temperate southern hemisphere. In: Bird Population Studies: Relevance to Conservation and Management (Ed. by C. M. Perrins, J.-D. Lebreton \& G. J. M. Hirons), pp. 22-44. New York: Oxford University Press.

Rowley, I. 1973. The comparative ecology of Australian corvids IV. Nesting and the rearing the young to independence. Wildlife Research, 18, 91-129.

Secomb, D. 2005. Breeding biology and behaviour of the northern forest raven Corvus tasmanicus boreus. Australian Field Ornithology, 22, 126-136.

Sedgwick, J. A. 1993. Reproductive ecology of dusky flycatchers in western Montana. Wilson Bulletin, 105, 84-92.

Sheldon, B. C. 2002. Relating paternity to paternal care. Philosophical Transactions of the Royal Society B, 357, 341-350.

Siefferman, L. \& Hill, G. E. 2005. Blue structural coloration of male eastern bluebirds Sialia sialis predicts incubation provisioning to females. Journal of Avian Biology, 36, 488-493.

Simon, J. C., Pratt, T. K., Berlin, K. E. \& Kowalsky, J. R. 2000. Reproductive ecology of the Maui parrotbill. Wilson Bulletin, 112, 482-490.

Skutch, A. F. 1962. The constancy of incubation. Wilson Bulletin, 74, 115-152.

Snyder, D. P. \& Cassel, J. F. 1951. A late summer nest of the red crossbill in Colorado. Wilson Bulletin, 63, 177-180.

Sturm, L. 1945. A study of the nesting activities of the American redstart. Auk, 62 , 189-206.

Tewksbury, J. J., Martin, T. E., Hejl, S. J., Kuehn, M. J. \& Jenkins, J. W. 2002. Parental care of a cowbird host: caught between the costs of egg-removal and nest predation. Proceedings of the Royal Society B, 269, 423-429.

Thompson, F. R. 2007. Factors affecting nest predation on forest songbirds in North America. Ibis, 149, 98-109.

Thomson, D. L., Monaghan, P. \& Furness, R. W. 1998. The demands of incubation and avian clutch size. Biological Reviews, 73, 293-304.

Tweed, E. J., Foster, J. T., Woodworth, B. L., Monahan, W. B., Kellerman, J. L. \& Lieberman, A. 2006. Breeding biology and success of a reintroduced population of the critically endangered puaiohi (Myadestes palmeri). Auk, 123, $753-763$.

Van Riper, C., III 1980. Observations on the breeding of the palila Psittirostra bailleui of Hawaii. Ibis, 122, 462-475.

VanderWerf, E. A. 1998. Breeding biology and territoriality of the Hawaii creeper Condor, 100, 541-545.

Verbeek, N. A. M. 1973. The exploitation system of the yellow-billed magpie. University of California Publications in Zoology, 99, 1-58.

Webb, D. R. 1987. Thermal tolerance of avian embryos: a review. Condor, 89 $874-898$.

Weidinger, K. 2008. Identification of nest predators: a sampling perspective. Journal of Avian Biology, 39, 640-646.

Williams, J. B. 1996. Energetics of avian incubation. In: Avian Energetics and Nutritional Ecology (Ed. by C. Carey), pp. 375-415. London: Chapman \& Hall.

Wood, K. A. 2001. Aspects of breeding of the pied currawong Strepera graculina at Wolongong, New South Wales. Corella, 25, 85-93.

Yom-Tov, Y., McCleery, R. \& Purchase, D. 1992. The survival rate of Australian passerines. Ibis, 134, 374-379.

Zanette, L., Doyle, P. \& Trémont, S. M. 2000. Food shortage in small fragments: evidence from an area-sensitive passerine. Ecology, 81, 1654-1666. 


\section{Appendix}

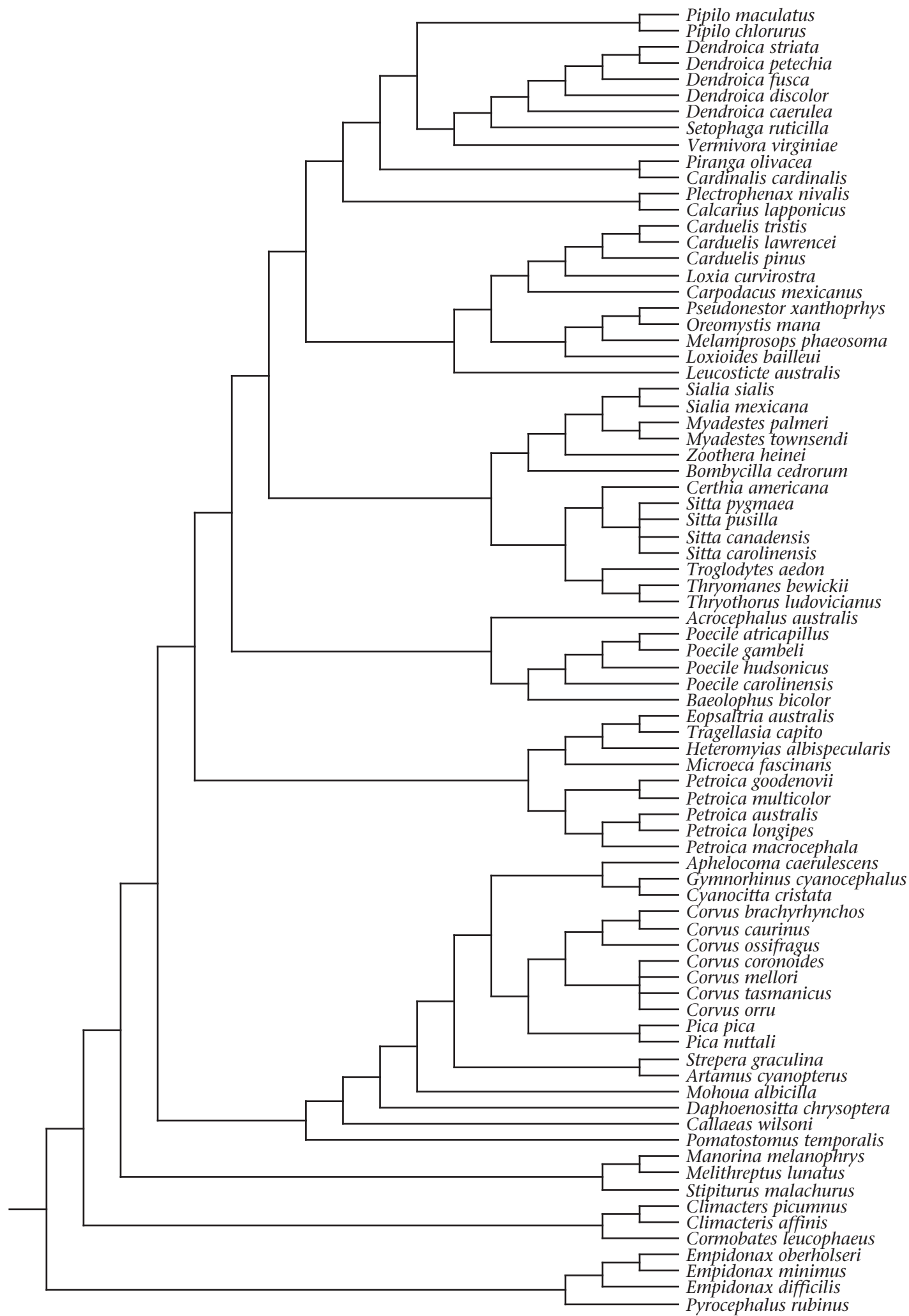

Figure A1. Our working phylogeny used for the phylogeny-corrected analyses. 
Table A1

The data set we used for the analysis

\begin{tabular}{|c|c|c|c|c|c|c|c|c|c|c|}
\hline Species & Family & IF & $\mathrm{BM}$ & LAT & TEMP & ATT & DPR & SOC & CONT & Source \\
\hline Aphelocoma coerulescens & Corvidae & 0.82 & 76.04 & 27.30 & 21.21 & 86.00 & 0.015 & Coop & NAm & Amadon 1944 \\
\hline Baeolophus bicolor & Paridae & 2.45 & 21.60 & 38.98 & 16.89 & 73.00 & 0.005 & Coop & NAm & Offutt 1965 \\
\hline Bombycilla cedrorum & Bombycillidae & 1.50 & 33.67 & 42.79 & 19.46 & 88.40 & 0.014 & Pair & NAm & $\begin{array}{l}\text { Putnam 1949, } \\
\text { Poole \& Gill 1992-2002 }\end{array}$ \\
\hline Calcarius lapponicus & Emberizidae & 0.02 & 28.18 & 68.55 & 5.15 & 71.70 & 0.034 & Pair & NAm & Lyon \& Montgomerie 1987 \\
\hline Cardinalis cardinalis & Cardinalidae & 0.62 & 44.05 & 39.87 & 17.40 & 70.00 & 0.045 & Pair & NAm & Jawor \& Breitwisch 2006 \\
\hline Carduelis lawrencei & Fringillidae & 1.02 & 10.55 & 36.38 & 14.79 & 96.70 & & Pair & NAm & Linsdale 1957 \\
\hline Carduelis pinus & Fringillidae & 2.00 & 15.00 & 40.80 & 18.87 & 95.00 & 0.007 & Pair & NAm & Perry 1965 \\
\hline Carduelis tristis & Fringillidae & 0.76 & 12.99 & 42.45 & 23.04 & 94.82 & 0.015 & Pair & NAm & Bent 1968 \\
\hline Carpodacus mexicanus & Fringillidae & 1.70 & 21.75 & 32.60 & 20.82 & 77.00 & 0.016 & Pair & NAm & Nolan et al. 2001 \\
\hline Certhia americana & Certhiidae & 1.49 & 8.40 & 34.25 & 22.96 & 82.50 & 0.004 & Pair & NAm & $\begin{array}{l}\text { Martin \& Ghalambor 1999, } \\
\text { Ghalambor \& Martin } 2002\end{array}$ \\
\hline Corvus brachyrhynchos & Corvidae & 3.23 & 506.00 & 27.30 & 23.41 & 83.25 & 0.012 & Coop & NAm & Kilham 1989 \\
\hline Corvus caurinus & Corvidae & 1.44 & 384.00 & 49.42 & 11.30 & 86.00 & 0.004 & Coop & NAm & $\begin{array}{l}\text { Butler et al. 1994, } \\
\text { Poole \& Gill 1992-2002 }\end{array}$ \\
\hline Corvus ossifragus & Corvidae & 0.59 & 285.05 & 34.96 & 17.92 & 82.76 & & Coop & NAm & $\begin{array}{l}\text { McNair 1984, } \\
\text { Poole \& Gill 1992-2002 }\end{array}$ \\
\hline Cyanocitta cristata & Corvidae & 0.20 & 71.64 & 38.95 & 20.80 & 94.07 & 0.012 & Pair & NAm & Hardy 1961 \\
\hline Dendroica cerulea & Parulidae & 0.10 & 8.20 & 44.50 & 15.90 & 85.19 & 0.006 & Pair & NAm & Oliarnyk \& Robertson 1996 \\
\hline Dendroica discolor & Parulidae & 0.06 & 7.50 & 39.17 & 20.74 & 76.90 & 0.033 & Pair & NAm & Nolan 1958,1978 \\
\hline Dendroica fusca & Parulidae & 0.16 & 10.20 & 46.28 & 17.32 & 77.00 & & Pair & NAm & Lawrence 1953 \\
\hline Dendroica striata & Parulidae & 0.02 & 11.96 & 44.58 & 10.79 & 72.20 & 0.008 & Pair & NAm & Poole \& Gill 1992-2002 \\
\hline Dendroica petechia & Parulidae & 4.13 & 9.80 & 46.48 & 19.26 & 91.90 & 0.016 & Pair & NAm & $\begin{array}{l}\text { Kendeigh 1952, } \\
\text { Tewksbury et al. } 2002\end{array}$ \\
\hline Empidonax difficilis & Tyrannidae & 0.03 & 10.66 & 36.37 & 15.65 & 79.66 & 0.009 & Pair & NAm & Davis et al. 1963 \\
\hline Empidonax minimus & Tyrannidae & 2.83 & 10.43 & 37.37 & 23.52 & 79.34 & 0.020 & Pair & NAm & Davis 1959 \\
\hline Empidonax oberholseri & Tyrannidae & 2.41 & 10.95 & 43.79 & 18.94 & 76.34 & 0.027 & Pair & NAm & Sedgwick 1993, Dobbs 2005 \\
\hline Gymnorhinus cyanocephalus & Corvidae & 0.82 & 105.00 & 35.20 & 4.80 & 92.70 & 0.016 & Coop & NAm & $\begin{array}{l}\text { Marzluff \& Balda 1992, } \\
\text { Poole \& Gill 1992-2002 }\end{array}$ \\
\hline Leucosticte australis & Fringillidae & 0.36 & 27.37 & 39.98 & 21.49 & 81.82 & & Pair & NAm & Poole \& Gill 1992-2002 \\
\hline Loxia curvirostra & Fringillidae & 0.25 & 31.79 & 41.61 & 18.46 & 98.20 & & Pair & NAm & $\begin{array}{l}\text { Lawrence 1949, } \\
\text { Snyder \& Cassel } 1951\end{array}$ \\
\hline Loxioides bailleui & Drepanididae & 0.87 & 37.50 & 19.80 & 24.08 & 81.95 & 0.004 & Coop & NAm & Van Riper 1980 \\
\hline Melamprosops phaeosoma & Drepanididae & 0.38 & 25.50 & 20.78 & 23.58 & 80.19 & & Pair & NAm & Kepler et al. 1996 \\
\hline Myadestes palmeri & Turdidae & 0.05 & 39.80 & 22.10 & 24.87 & 77.00 & 0.014 & Coop & NAm & Tweed et al. 2006 \\
\hline Myadestes townsendi & Turdidae & 0.80 & 32.50 & 40.65 & & 94.67 & 0.020 & Pair & NAm & Poole \& Gill 1992-2002 \\
\hline Oreomystis mana & Drepanididae & 0.19 & 14.65 & 19.85 & 22.83 & 86.33 & & Pair & NAm & VanderWerf 1998 \\
\hline Poecile atricapillus & Paridae & 1.89 & 10.80 & 43.23 & 14.34 & 75.58 & 0.012 & Pair & NAm & $\begin{array}{l}\text { Odum 1942, Brewer 1961, } \\
\text { Otter et al. } 1999\end{array}$ \\
\hline Poecile hudsonicus & Paridae & 0.52 & 9.80 & 45.80 & 12.59 & 80.44 & & Pair & NAm & McLaren 1975 \\
\hline Pica nuttalli & Corvidae & 2.65 & 150.95 & 36.38 & 11.30 & 92.55 & 0.005 & Pair & NAm & Verbeek 1973 \\
\hline Pica pica & Corvidae & 0.95 & 173.88 & 42.39 & 14.15 & 91.77 & 0.007 & Pair & NAm & Erpino 1968, Buitron 1988 \\
\hline Pipilo chlorurus & Emberizidae & 0.04 & 28.90 & 34.25 & 24.12 & 75.43 & 0.049 & Pair & NAm & Poole \& Gill 1992-2002 \\
\hline Pipilo maculatus & Emberizidae & 0.10 & 39.38 & 36.38 & 14.46 & 79.70 & 0.026 & Pair & NAm & Davis 1960 \\
\hline Piranga olivacea & Thraupidae & 1.36 & 28.25 & 41.77 & 18.98 & 76.73 & 0.015 & Pair & NAm & Klatt et al. 2008 \\
\hline Plectrophenax nivalis & Emberizidae & 3.60 & 34.37 & 68.55 & 3.14 & 79.75 & 0.015 & Pair & NAm & Lyon \& Montgomerie 1985 \\
\hline Poecile carolinensis & Paridae & 1.70 & 10.43 & 39.72 & 20.31 & 77.20 & 0.003 & Pair & NAm & Brewer 1961 \\
\hline Poecile gambeli & Paridae & 4.18 & 11.29 & 34.25 & 23.01 & 86.50 & 0.003 & Pair & NAm & $\begin{array}{l}\text { Martin \& Ghalambor 1999, } \\
\text { Ghalambor \& Martin } 2002\end{array}$ \\
\hline Pseudonestor xanthophrys & Drepanididae & 0.31 & 22.25 & 20.75 & 23.70 & 75.94 & 0.005 & Pair & NAm & Simon et al. 2000 \\
\hline Pyrocephalus rubinus & Tyrannidae & 0.72 & 12.67 & 34.73 & 13.47 & 72.33 & 0.011 & Pair & NAm & Poole \& Gill 1992-2002 \\
\hline Setophaga ruticilla & Parulidae & 0.24 & 7.83 & 41.65 & 21.91 & 85.25 & 0.016 & Pair & NAm & Sturm 1945 \\
\hline Sialia mexicana & Turdidae & 2.53 & 26.45 & 36.38 & 14.48 & 77.28 & 0.003 & Coop & NAm & Dickinson \& Leonard 1995 \\
\hline Sialia sialis & Turdidae & 1.20 & 29.75 & 32.58 & 21.29 & 52.50 & 0.002 & Pair & NAm & Siefferman \& Hill 2005 \\
\hline Sitta canadensis & Sittidae & 5.90 & 10.54 & 34.25 & 23.06 & 88.87 & 0.002 & Pair & NAm & $\begin{array}{l}\text { Martin \& Ghalambor 1999, } \\
\text { Ghalambor \& Martin } 2002\end{array}$ \\
\hline Sitta carolinensis & Sittidae & 5.80 & 21.10 & 36.30 & 20.72 & 93.14 & 0.002 & Pair & NAm & $\begin{array}{l}\text { Ritchison 1981, Martin \& } \\
\text { Ghalambor 1999, } \\
\text { Ghalambor \& Martin } 2002\end{array}$ \\
\hline Sitta pusilla & Sittidae & 1.73 & 10.10 & 32.02 & 23.68 & 78.60 & 0.015 & Coop & NAm & $\begin{array}{l}\text { Norris } 1958 \text {, Poole \& } \\
\text { Gill 1992-2002 }\end{array}$ \\
\hline Sitta pygmaea & Sittidae & 7.41 & 10.77 & 34.82 & 21.66 & 86.40 & 0.001 & Coop & $\mathrm{NAm}$ & $\begin{array}{l}\text { Norris 1958, Martin \& } \\
\text { Ghalambor 1999, } \\
\text { Ghalambor \& Martin } 2002\end{array}$ \\
\hline Thryomanes bewickii & Troglodytidae & 1.50 & 9.76 & 39.10 & 19.88 & 70.00 & 0.003 & Pair & NAm & Pearse et al. 2004 \\
\hline Thryothorus ludovicianus & Troglodytidae & 0.68 & 20.50 & 34.77 & 19.20 & 67.35 & 0.031 & Pair & NAm & Nice \& Thomas 1948 \\
\hline Troglodytes aedon & Troglodytidae & 0.07 & 10.80 & 40.15 & 19.11 & 57.70 & 0.011 & Pair & NAm & $\begin{array}{l}\text { Johnson \& Kermott 1992, } \\
\text { Pearse et al. } 2004\end{array}$ \\
\hline Vermivora virginiae & Parulidae & 0.08 & 8.20 & 34.25 & 23.54 & 73.70 & 0.026 & Pair & NAm & Martin \& Ghalambor 1999 \\
\hline Acrocephalus australis & Sylviidae & 0.07 & 19.13 & 38.03 & 17.85 & 52.00 & 0.012 & Pair & AuNZ & Eikenaar et al. 2003 \\
\hline Callaeas wilsoni & Callaeidae & 0.93 & 225.50 & 38.52 & 16.10 & 85.51 & 0.013 & Pair & AuNZ & Innes \& Hay 1995 \\
\hline Cormobates leucophaea & Climacteridae & 1.32 & 21.25 & 33.27 & 14.46 & 70.46 & & Pair & AuNZ & Noske 1991, Doerr 2004 \\
\hline Climacteris affinis & Climacteridae & 0.56 & 20.83 & 34.42 & 18.49 & 59.80 & 0.009 & Coop & AuNZ & Radford 2002 \\
\hline
\end{tabular}


Table A1 (continued)

\begin{tabular}{|c|c|c|c|c|c|c|c|c|c|c|}
\hline Species & Family & IF & $\mathrm{BM}$ & LAT & TEMP & ATT & DPR & SOC & CONT & Source \\
\hline Climacteris picumnus & Climacteridae & 2.26 & 32.26 & 33.48 & 14.54 & 65.88 & & Coop & AuNZ & $\begin{array}{l}\text { Noske 1991, Doerr 2004, } \\
\text { Doerr \& Doerr } 2007\end{array}$ \\
\hline Corvus coronoides & Corvidae & 2.00 & 612.96 & 34.60 & 8.47 & & & Pair & AuNZ & Rowley 1973 \\
\hline Corvus mellori & Corvidae & 2.00 & 507.07 & 35.20 & 12.90 & & & Pair & AuNZ & Rowley 1973 \\
\hline Corvus orru & Corvidae & 2.00 & 562.76 & 26.80 & 18.00 & & & Pair & AuNZ & Rowley 1973 \\
\hline Corvus tasmanicus & Corvidae & 0.76 & 658.65 & 30.63 & 16.43 & 94.37 & & Pair & AuNZ & Secomb 2005 \\
\hline Daphoenositta chrysoptera & Neosittidae & 3.50 & 12.80 & 35.93 & 14.55 & 69.81 & 0.005 & Coop & AuNZ & Marchant 1984 \\
\hline Eopsaltria australis & Petroicidae & 3.51 & 19.42 & 30.50 & 14.44 & 82.63 & 0.039 & Coop & AuNZ & $\begin{array}{l}\text { Zanette et al. 2000, } \\
\text { Debus et al. } 2004\end{array}$ \\
\hline Heteromyias albispecularis & Petroicidae & 0.84 & 35.50 & 17.42 & 20.15 & 63.53 & 0.013 & Pair & AuNZ & Frith \& Frith 2000 \\
\hline Manorina melanophrys & Meliphagidae & 0.83 & 27.81 & 37.65 & 16.35 & & 0.013 & Coop & AuNZ & Poiani 1992 \\
\hline Melithreptus lunatus & Meliphagidae & 1.25 & 13.95 & 35.93 & 14.60 & 77.00 & & Coop & AuNZ & Marchant 1986 \\
\hline Mohoua albicilla & Pachycephalidae & 0.39 & 16.68 & 36.18 & 12.85 & 74.30 & & Coop & AuNZ & Gill 1993 \\
\hline Petroica australis & Petroicidae & 2.46 & 36.32 & 42.33 & 13.07 & 80.31 & 0.020 & Pair & AuNZ & Powlesland 1983 \\
\hline Petroica goodenovii & Petroicidae & 5.21 & 8.79 & 36.23 & 16.01 & 78.20 & 0.034 & Pair & AuNZ & Coventry 1988 \\
\hline Petroica longipes & Petroicidae & 2.80 & 28.17 & 38.53 & 13.48 & 72.50 & 0.017 & Pair & AuNZ & Boulton et al. 2010 \\
\hline Petroica macrocephala & Petroicidae & 1.98 & 11.14 & 43.70 & 10.74 & 72.50 & 0.027 & Pair & AuNZ & Kearton 1979 \\
\hline Petroica multicolor & Petroicidae & 1.63 & 12.90 & 36.23 & 16.01 & 79.10 & 0.033 & Pair & AuNZ & Coventry 1989 \\
\hline Pomatostomus temporalis & Pomatostomidae & 3.15 & 72.48 & 27.78 & 20.56 & 81.72 & 0.008 & Coop & AuNZ & King 1980 \\
\hline Stipiturus malachurus & Maluridae & 0.43 & 7.24 & 38.38 & 14.97 & 58.50 & 0.007 & Coop & AuNZ & Maguire \& Mulder 2004 \\
\hline Strepera graculina & Cracticidae & 0.83 & 308.17 & 34.42 & 17.28 & 69.37 & 0.003 & Pair & AuNZ & Wood 2001 \\
\hline Tregellasia capito & Petroicidae & 3.00 & 13.78 & & & 55.00 & & Coop & AuNZ & Higgins \& Peter 2002 \\
\hline Zoothera heinei & Turdidae & 2.20 & 82.35 & 28.43 & 19.68 & 84.90 & 0.022 & Pair & AuNZ & Higgins et al. 2006 \\
\hline
\end{tabular}

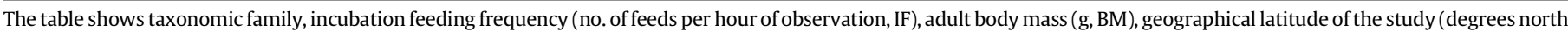

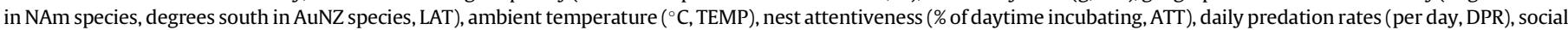

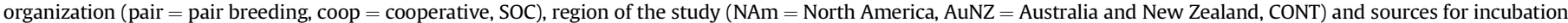
feeding data for individual species of songbird. 